\title{
Fiscal decentralization and convergence in government spending in Malaysia
}

\author{
Yusniliyana Yusof $^{1}$ (0) | Kaliappa Kalirajan $^{2}$ | Azhar Mohamad $^{1}$
}

${ }^{1}$ Department of Finance, Kulliyyah of Economics and Management Sciences, International Islamic University Malaysia, Malaysia

${ }^{2}$ Crawford School of Public Policy, The Australian National University, Australia

\section{Correspondence}

Yusniliyana Yusof, Department of Finance, Kulliyyah of Economics and Management Sciences, International Islamic University Malaysia, 53100 Kuala Lumpur, Malaysia.

Email: yusniliyana@iium.edu.my

\begin{abstract}
In this study, we highlight the influence of the federal system on the development expenditure of the states, which is crucial for socio-economic development. First, we examine whether there is a convergence in development expenditure across Malaysian states. Second, we investigate the importance of decentralization in affecting the pattern of development expenditure in the short-term and in the long-term. The convergence analysis utilizes annual growth data from 2000 through 2015 for the short-term and the averages of 3and 5-year growth for the long-term. In this study, we employ the panel data approaches of pooled OLS, fixed effects and random effects estimation procedures. The findings provide empirical evidence of the convergence of development expenditure across the states in Malaysia in both the short-term and the long-term. Generally, all fiscal decentralization indicators (state per capita revenue, state own-source per capita revenue, state own-source revenue as a share of total revenue and inter-state fiscal capacity) are imperative in influencing the fiscal behaviour of state governments in Malaysia. These indicators, as well as assistance from the federal government in the form of transfer payment, are very much needed to strengthen the expenditure capacity of the Malaysian states.
\end{abstract}

\section{K E Y W O R D S}

convergence, government spending, decentralization, developing country

J E L C L A S S I F I C A T I O N

$\mathrm{H} 30 ; \mathrm{H} 72 ; \mathrm{H} 77$; $\mathrm{O} 23$

\section{1 | INTRODUCTION}

Malaysia, which aspires to reach high-income status in 2024, has targeted sustainable and inclusive growth that is emphasized not only in the economic sector, but also in terms of social welfare. The Eleventh Malaysia Plan (11th MP-2016 to 2020) has laid out crucial steps for Malaysia to follow to become an advanced nation (Economic Planning Unit, 2015). The Malaysia Plan highlights six thrusts: to enhance inclusiveness for an equitable society, improve the well-being of the people, accelerate human capital development, pursue green growth, strengthen the infrastructure and promote innovation and productivity. According to the Malaysia Plan report, there has been an increase in socio-economic status. It has been observed that the Gini coefficient fell to 0.401 in 2014 from 0.441 in 2009, and that the mean monthly household income of the bottom $40 \%$ of households increased from RM 1440 in 2009 to RM 2537 in 2014. These are evidences of improvement in overall 
income distribution in Malaysia. The Malaysian Well Index (MWI), which presents both economic and social well-being sub composite indices, also improved over the period from 2000 to 2012, by 25.4 points (Economic Planning Unit, 2013). Regardless of these developments, more attention is required to ensure spatial balance in economic and social well-being across regions, states or individuals to reflect equity and equality within a society.

Given the concern over regional imbalances, Malaysia has focused on regional economic corridors' plans to address the issues and to ensure that local communities benefit from development achieved in the region. Despite these initiatives, more must be done to ensure that development gaps across states do not broaden and that the pattern of socio-economic development is fairly distributed across the states or local communities. The role of institutional factors in conducting development policies and allocating spending in an effective way cannot be neglected. The country might have similar resources or spending but different development outcomes due to other factors such as governance and institutions. According to the Post-Washington Consensus, different institutional factors and country-specific organizations have been major constraints against the achievement of similar results from policies across states (Kalirajan \& Otsuka, 2012). The difference in state-level effectiveness lies in the capacities of the different states as well as in the political and administrative rule. In this context, one of the major considerations in relation to public finance and development plans is the presence of decentralization.

Decentralization or the devolution of political, fiscal and administrative power from the central to the subnational governments may be significant in facilitating spatially equitable development (Kim, 2008). Socioeconomic indicators are expected to improve with the provision of local public services, which are theoretically agreed upon as being more efficiently delivered through decentralization. Some studies have found that decentralization promotes efficiency in public service (Kim, 2008; Sow \& Razafimahefa, 2015). The function of decentralization is delivered effectively if there is a declining variation in spatial socio-economic development. Nevertheless, due to the different fiscal capacities resulting from decentralization, states find it challenging to offer an equitable level of public services (Boadway, 2001). However, incomparable levels of public services at the state level are not due only to the revenue-raising capacity but also to the need for, and the costs of provision of, public services.

Each state is entitled to a similar level of public services, which means the population in any area should have the same access to education and training, health, crime prevention and other services (Mackay, 2001, as cited in Gripaios, 2002). Government spending is endogenous to a country's inclusive growth, used to build infrastructure, human capital and social capital. Spending is expected to promote improved social and economic development through the provision of services. Different levels of government spending on the provision of public services may reflect different levels of access to public services across regions. Faguet and Shami (2008) suggest that local specific investment is the best way to overcome the spatial inequality that results from variations in infrastructure or public assets, while investment in connectivity-type goods is the best way to foster equality with respect to differential access to markets, or to a particular resource (e.g., a natural resource, or knowledge and information).

Because variation in public services has been a major cause of spatial imbalance, we seek to examine the pattern of fiscal spending across states on social and economic development. We also examine whether the distribution of development expenditure across developed and less developed states in Malaysia is likely to be "converging" or "diverging" over time. The Federation of Malaysia consists of federal and state governments that are responsible for national development as a whole. In this context, we attempt to analyze whether decentralization indicators and federal transfers affect the development expenditure pattern across Malaysian states. Additionally, we compare the evidence of convergence in the short-term and the long-term.

We contribute to the growing debate over Malaysian development in several ways. First, we highlight the empirical evidence of the equitable distribution of socioeconomic development across states through convergence in government spending. The findings of the study reflect the fact that less developed states were catching up to developed states during the period of 2000-2015. Despite this, the moderate performance of less developed states in terms of catching up to developed states is better understood by evaluating the factors that explain changes in the pattern of government spending across states. In this regard, we demonstrate that the unresolved issues in the development gaps across Malaysian states might be a result of the Malaysian federalism system, which places financial matters resolutely in federal government authority. We infer that the functioning of state government matters in terms of ensuring spatially equitable socio-economic development across states in Malaysia.

Moreover, the study on the convergence in development expenditure, along with the impact of decentralization indicators on the pattern of development expenditure growth across Malaysian states, have not 
been analyzed before. This provides a motivation for our study. Prior studies have evidenced that institutional factors, such as governance and decentralization, could influence government spending. In the context of other emerging economies, namely India, Kalirajan and Otsuka (2012) find that decentralization is important in cultivating growth in government expenditure across the states. In addition, Garg (2015) reports that subnational governments' expenditure across Indian states could be strengthened through better governance and central government transfers. In this regard, we aim to investigate whether decentralization plays a role in facilitating growth in development expenditure, which is crucial to promoting spatial balance in socio-economic development across states in Malaysia.

The remainder of the paper is structured as follows. The next section discusses federalism and intergovernmental relationships in Malaysia. It is followed by reviews of the literature on convergence in state government expenditure and a presentation of the data and methodology. This is followed by the findings, the conclusion and the implication of this study.

\section{2 | FEDERATION OF MALAYSIA}

The Malaysian Constitution, as a framework for the country's inter-governmental relationships, governs the Federation of Malaysia. The Ninth Schedule of the Constitution highlights the legislative powers of the federal territories and states in Malaysia. Federal and state laws are split into three categories: federal, state and concurrent (both federal and state governments) powers. The Parliament may create laws for the whole country, or for any matters on a federal list or the concurrent list, where the effects of the laws may be both external and within the federation. The lists show that the federal government has legislative authority over the states in most matters, including social and economic areas such as trade, commerce and industry, shipping, communication and transport, education, and medicine and health. Meanwhile, the state governments deal with Muslim issues and practices, lands and mines, agriculture and forestry, local government and public services such as graveyards, markets and fairs, cinemas and theatre licences, state government machinery and water, state holidays, offences and compensation with regard to state matters, and turtles and river fishing.

Both federal and state governments share responsibilities for social well-being, scholarships, birds and wildlife conservation, town and country planning, drainage and irrigation, public health, culture and sports, housing and water services. Federal government power prevails if there is an inconsistency between federal and state law. In Malaysia, the power of the states to pursue their socioeconomic development portfolios of healthcare, education and infrastructure is limited to federal autonomy, as these matters are governed by the law set up by the federal government. This implies that the welfare of people across the states depends greatly on the federal government, though public service functions may be administered by different states. Finally, Sabah and Sarawak are granted special constitutional status in both the state list and the concurrent list, as reflected in the supplementary list in Table 1.

An important feature of Malaysian federalism is the placing of financial matters firmly in federal government hands (Federal Constitution of Malaysia, 2009). A state has limited power to borrow, being allowed to borrow only directly from the federal government or, when given approval by the federal government, from a bank or other financial source for a period not exceeding 5 years. The Constitution lays out limited powers for the states in terms of taxation and other sources of revenue, in Article 110 and Part III of the tenth schedule. Almost all kinds of taxable income are vested to the federal government, while the state is provided with royalties derived from petroleum, export duties on minerals such as tin, ores, metals and other mineral oils produced in the state, excise duties on toddy shops, forests, land and mines, and excise duties on entertainment. Other sources of revenue include rental charges on state property, licencing fees, charges on water, and Islamic religious revenue, that is, Zakat, Fitrah and Baitumal. Despite all these sources of revenue, all the powers with respect to the taxation of minerals are delivered to the federal government. In return, the federal government pays each individual state a portion of the export duties levied on that state's production. Petroleum revenues are treated differently from the above; the royalty-sharing arrangements between the federal and state governments for offshore oil are counted directly as state government revenue, and not as a grant from the federal government.

\section{3 | CONVERGENCE IN STATE GOVERNMENT EXPENDITURE}

The past behaviour in terms of expenditure development across Malaysian state governments can be quantified based on convergence theory. Barro and Sala-i-Martin (1990) discuss two definitions of the concept of convergence. First, convergence implies the growth of per capita income in one economy against the growth of per capita income across all economies ( $\beta$-convergence). Conversely, the second definition of convergence relates to the increase or decrease in cross-sectional dispersion of per capita income over time ( $\sigma$-convergence). 
TABLE 1 Distribution of legislative powers between Federation and states

\begin{tabular}{|c|c|c|}
\hline Federal list & State list & Concurrent list (federal-state) \\
\hline 2. Defence & 2. Land & 2. Scholarship \\
\hline \multirow{2}{*}{$\begin{array}{l}\text { 4. Civil and criminal law and justice } \\
\text { legal system }\end{array}$} & 4. Local government & 4. Animal husbandry \\
\hline & \multirow{3}{*}{$\begin{array}{l}\text { 5. Local facilities - lodging houses, } \\
\text { graveyards, pounds and cattle } \\
\text { trespassing, markets and fairs, and } \\
\text { theatres and cinema licences }\end{array}$} & 5. Town and country planning \\
\hline 5. Nationality and citizenship & & $\begin{array}{l}\text { 6. Vagrancy law and licencing of } \\
\text { itinerant hawkers }\end{array}$ \\
\hline 7. Finance & & 7. Public health \\
\hline 8. Trade, industry and commerce & 6. Machinery of state government & 8. Irrigation and drainage \\
\hline 9. Shipping, navigation and fisheries & 7. State controls and water & 9. Mine and land rehabilitation \\
\hline 10. Communication and transport & 8. State holidays & 10. Fire safety measures \\
\hline 11. Federal works and control & 9. State purposes inquiries & 11. Culture and sports \\
\hline $\begin{array}{l}\text { 12. Surveys, inquiries and research } \\
\text { 13. Education }\end{array}$ & $\begin{array}{l}\text { 10. Offences and compensation in } \\
\text { regard to state matters }\end{array}$ & $\begin{array}{l}\text { 12. Housing and accommodation } \\
\text { provisions }\end{array}$ \\
\hline 16. Aborigines' welfare & \multirow{4}{*}{$\begin{array}{l}\text { Supplement to state list for the states of } \\
\text { Sabah and Sarawak } \\
\text { 1. Native law and customs } \\
\text { 2. Incorporation of state authorities and } \\
\text { other organizations }\end{array}$} & $\begin{array}{l}\text { Supplement to state list for the states of } \\
\text { Sabah and Sarawak } \\
\text { 1. Personal law }\end{array}$ \\
\hline 17. Licencing the professional & & 2. Adulterated food and other goods \\
\hline 18. Federal holidays & & 3. Below 15 tons shipping \\
\hline 19. Unincorporated societies & & 4. Water power \\
\hline 20. The control of agriculture pests & $\begin{array}{l}\text { 3. Ports and harbours not included in } \\
\text { federal control }\end{array}$ & 5. Research in agriculture and forestry \\
\hline 22. Censorship & 4. Cadastral surveying & \multirow{4}{*}{$\begin{array}{l}\text { 7. Theatres, cinemas and places for } \\
\text { entertainment }\end{array}$} \\
\hline 23. Theatres and cinemas & 5. Museum and library & \\
\hline $\begin{array}{l}\text { 24. Improvement trusts and federal } \\
\text { housing }\end{array}$ & \multirow[t]{2}{*}{ 6. The Sabah railway in Sabah } & \\
\hline 25. Incorporated societies & & \\
\hline
\end{tabular}

Note: This table shows the subject matter of the federal and state laws, which are split into three categories: federal, state and concurrent (both federal and state governments) powers.

Source: The Constitution of Malaysia, as cited in Anuar (2000).

The standard neo-classical approach of Solow's (1956) growth model predicts that absolute convergence happens, as more developed and capital-abundant countries experience a diminishing marginal return of capital and labour. As a result, there is a flow of capital and labour to less-capital-abundant countries and higher wages, hence raising the productivity in these countries. All parameters (e.g., population growth rate, saving rate, production function) are assumed to be similar so that economies will have the same steady state in their capital-labour ratio and income. Moving towards their steady states, economies with lower values of initial capital-labour ratio and income (i.e., poor economies) tend to have higher growth in their capital-labour ratio and also higher growth in income as compared to economies with higher initial capital (i.e., rich economies). This condition implies that there is a convergence of poor countries or regions towards those with a higher capital-labour ratio and income.

Conditional convergence is obtained by controlling the other determinants of the stable state (Kaitila, 2005).
According to this hypothesis, we correct for differences in the steady states of the capital-labour ratio and income, or for other structural characteristics, and the convergence occurs as the per capita income in a country moves towards its long-run growth path. Countries with lower per capita income are projected to have higher expected growth. The graphical differences between absolute and conditional convergence are explained in a study conducted by Timakova (2011). Both concepts state that countries will converge to one identical point. Hence, the results of convergence can be observed after controlling the structural differences in the economy, as represented by the negative relationship between the initial level of income per capita and subsequent growth (Timakova, 2011).

Besides indicating income, the previous literature has investigated the degree of convergence in the area of public finance (Afxentiou \& Serletis, 1996; Annala, 2003; Apergis, Christou, \& Hassapis, 2013; Deller \& Skidmore, 2005; Pan, Wang, Qin, \& Zhang, 2013; Skidmore, Toya, \& Merriman, 2004). Earlier work by 
Annala (2003) adds three assumptions to explain convergence in government activity. These assumptions are (1) population growth is exogeneous, (2) the population and labour force are the same and (3) the tax imposed is a fixed proportion of output. Given a tax that is a constant proportion of output, the growth rate of the tax will equal the growth rate of output. Additionally, as taxes are used to finance government spending, the growth rate of government activity will equal both the growth rate of taxes and the growth rate of output. Applying the same concept of convergence as Solow (1956), Annala (2003) assumes that convergence of income or output is also related to convergence of taxes and government activity. The study tests for convergence in US fiscal policies in the areas of total taxes and three divisions of tax revenue (property, general sales and income tax), as well as five categories of local government expenditure (general, education, highways, welfare and hospital expenditure). The study reports some findings on convergence in those fiscal policies. Skidmore, Toya, and Merriman (2004) discuss the convergence in government expenditure on the basis of a theoretical model. The study shows that the level of government spending $\left(G_{t}\right)$ is a function of the share $\left(\tau_{t}\right)$ of previous output $\left(Q_{t-1}\right)$. On the other hand, per capita output, $q_{t}$ is given as a function of private capital $\left(k_{t}\right)$ and public inputs $\left(g_{t}\right)$. From these two functions, this study formulates the approximate production function with Cobb-Douglas constant returns to scale, as below:

$$
G_{t} \equiv \tau_{t} A L_{t-1} k_{t-1}^{\alpha} g_{t-1}^{\beta}
$$

From Equation (1), growth in per capita government expenditure is obtained as follows:

$$
\ln \left(\frac{g_{t}}{g_{t-1}}\right) \approx \ln A \tau_{t}-n_{t}+\alpha \ln k_{t-1}+(\beta-1) \ln g_{t-1}
$$

Based on Equation (2), government spending is specified as a function of lagged values of private $\left(k_{t-1}\right)$ and public $\left(g_{t-1}\right)$ capitals, growth of the population $\left(n_{t}\right)$ and its share of the total output $\left(\tau_{t}\right)$. Similar to private capital, government spending experiences diminishing marginal returns $(\beta<1)$. Therefore, with other variables held constant, the higher level of initial government expenditure is associated with lower growth in current government expenditure, and vice versa for a lower level of spending. Hence, there will be convergence in government expenditure over time.

This situation supports the convergence hypothesis as previously discussed. Skidmore et al. (2004) add that convergence happens due to the diminishing of marginal utility in consuming each additional unit of government goods and services. It is argued that the marginal benefit obtained from extra government spending is higher for citizens of countries with a low initial level of government spending than for those with a high level of government spending. As a result, countries with the former condition will increase their spending, hence experiencing very high growth rates that will allow them to catch up to countries with high initial levels of government spending.

Previous studies on convergence in government expenditure have focused on different categories of fiscal policies and expenditure, and they have reported mixed results (convergence: Zhang, Zhang, Wu, Xia, \& Lu, 2016 and Pan, Wang, Qin, \& Zhang, 2013 (government health expenditure); Garg, 2015 (education, health and development expenditure); Annala, 2003 (tax revenue, highway, education and general expenditure); Deller \& Skidmore, 2005 (protection services, road, waste services and quality of life services expenditure); Skidmore et al., 2004 (consumption, capital and education expenditure); divergence: Pan et al., 2013 (government health expenditure); Annala, 2003 (public welfare and health expenditure); Apergis, Christou, \& Hassapis, 2013 (public expenditure); Afxentiou \& Serletis, 1996 (subsidies)).

Along with convergence analysis, the literature has examined the impact of institutional factors on changes in government spending. A recent study by Garg (2015) includes governance and some categories of federal transfers as determinants of growth in government expenditure across Indian states. The study finds that better governance and transfers from the central government have strengthened the subnational governments' capacity to cultivate expenditure growth across states. In addition, Kalirajan and Otsuka (2012) use a decentralization index to determine the influence of the devolution of resources from the central government, and that of the state capacity to collect revenue, on tendencies in government spending. The study shows that a greater level of decentralization facilitates higher growth in government expenditure. In this study, we include decentralization indicators as well as federal transfers to examine their impact on the spatial equity pattern of Malaysian state governments' development expenditure. To the best of our knowledge, this study is the first to quantify the impact of decentralization indicators on the pattern of expenditure growth in the context of Malaysia.

Figure 1 depicts the pattern of inter-state differences in the growth of development expenditure between developed and less developed states for the three 5-year periods of 2001-2005, 2005-2010 and 2011-2015. Overall, the figure depicts the convergence of less developed states to developed states, in terms of their development expenditure, in some phases. Initially, the growth rate of 

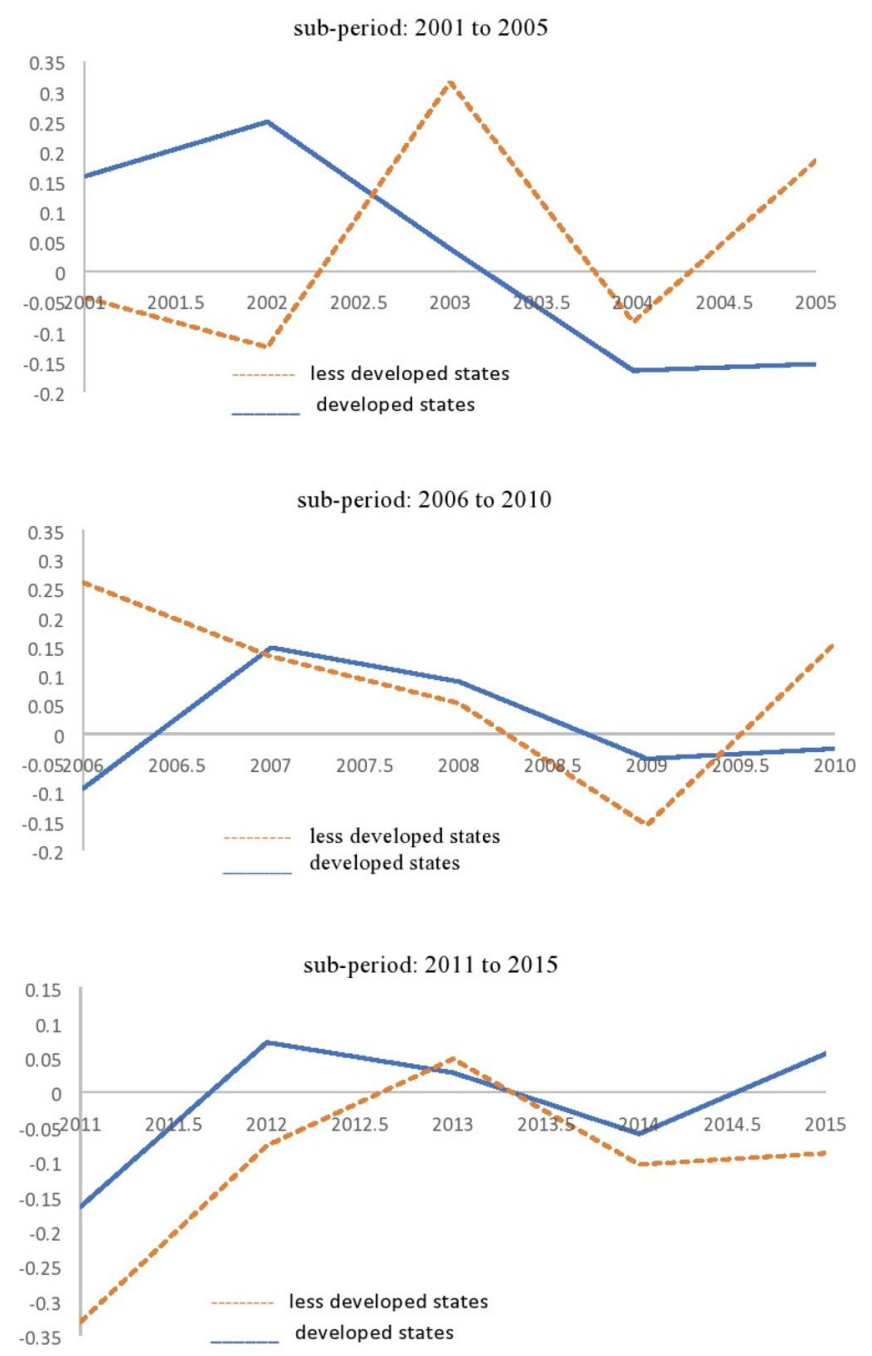

F I G URE 1 Growth rate of development expenditure between developed and less developed states. This figure depicts the pattern of inter-state differences in the growth of development expenditure between developed and less developed states for the three 5-year periods of 2001-2005, 2005-2010 and 2011-2015. Source: Author's calculation [Colour figure can be viewed at wileyonlinelibrary.com]

development expenditure in the developed states was higher than that of the less developed states. However, less developed states improved from 2002 to 2007, and again after 2009, when the higher expenditure growth in the less developed states was accompanied by a decline in the growth of expenditure in the developed states. From the year 2011 onwards, it has become evident that the less developed states are catching up to the developed states at a faster rate, with increasing growth rates of development expenditure. Following 2014, there has been an upward trend in the growth of development expenditure for both developed and less developed states. Further convergence analysis will be carried out using a regression framework on the convergence model, based on Barro and Sala-i-Martin's (1990) work, to reveal whether the development expenditure across Malaysian states is likely to be "converging" or "diverging" over time.

\section{4 | DATA AND METHODOLOGY}

The Federation of Malaysia consists of 3 federal territories and 13 state governments. As the three federal territories of Kuala Lumpur, Labuan and Putrajaya are administered by the federal government, we look at the 13 state governments, namely, Johor, Melaka, Negeri Sembilan, Pulau Pinang, Perak, Perlis, Selangor, Kedah, Kelantan, Pahang, Terengganu, Sabah and Sarawak, over the period from 2000 to 2015 . We retrieve data on expenditure and revenue from the yearly financial statements of state governments from the National Audit Department website. The data on transfers from the federal government are supplied by the Ministry of Finance, while state per capita GDPs (GSDP) and state-level populations are retrieved from the Economic Planning Unit, Prime Minister's Department. We use linear interpolation to obtain missing data on the GSDP for the years 2001, 2002 and 2004. We deflate expenditure, revenue and transfer variables using the consumer price index of 2010 as the base year, to obtain the values in real prices. GSDP is also at constant 2010 prices.

\section{1 | Model and specifications}

We analyze the disparity in state government expenditure based on the concept of the convergence model. As our study is interested in fiscal expenditure convergence in the Malaysian states, we use the $\beta$-convergence model to reveal the growth rate of poor economies in catching up with rich economies. The $\beta$-convergence describes the speed of convergence between states with lower per capita expenditure and those with higher spending per capita. We further examine the model based on two types of convergence: unconditional and conditional. Unconditional convergence is obtained by regressing the growth of real government expenditure only at its initial level. Meanwhile, conditional convergence refers to a condition in which a negative relationship exists between the initial level of government spending and its average growth rate after explanatory variables are controlled. We include revenue decentralization instruments to study the importance of institutional factors and other possible determinants that might affect the convergence of state governments' expenditure in Malaysia. This study's conditional convergence equation is an extension of Barro and Sala-i-Martin's (1990) methodology of income convergence as defined below: 


$$
\ln \frac{Y_{i t}}{Y_{i t-1}}=\alpha+\beta_{0} \ln Y_{i t-1}++\beta_{1}\left(\operatorname{Dec}_{i t}\right)+\beta_{1}\left(X_{i t}\right)+\varepsilon_{i, t}
$$

where $Y_{i t}$ refers to current per capita real expenditure of state " $i$," while $Y_{i t-1}$ denotes the initial level of per capita expenditure. The estimated coefficient of $Y_{i t-1}$ is expected to have a negative indication, implying the convergence of development expenditure across states. Next, variable revenue decentralization (Dec) is included to measure the impact of the fiscal autonomy of state governments on the development expenditure pattern. We postulate a positive sign for the estimated coefficient, which would infer that a state with more revenue has more fiscal capacity and, hence, higher expenditure than a state with lower revenue. On the other hand, $X_{i t}$ refers to the control variables of initial per capita GSDP and population growth of individual state " $i$ " in particular year " $t$."

With regard to revenue decentralization indicators, we employ total state revenue in the first model but, in the remaining three models, split the total revenue into transfers from the federal government and the fiscal capacity of the states. The inclusion of federal transfers helps us understand the level at which state governments rely on the federal government's assistance in making their development expenditure decisions. Meanwhile, the state's fiscal capacity is proxied by three different measures. The total state revenue at the per capita level is used in the second model while state own-source revenue as a share of total state revenue is used in the third model. In the fourth model, we use state own-source revenue as a share of the national average, where the national average is the total of all the state revenue divided by the number of states. While the first two measures describe the revenue capacity in a particular state, the third captures the inter-state difference in fiscal capacity in meeting expenditure responsibilities. Based on Wilson's (1996) work, state own-source revenue as a share of the national average is used to explain the horizontal balance across states, which in turn reveals the variation in the amount of per capita own-source revenue available to each state out of the national average.

Initial per capita GSDP and population growth are included as the control variables. Guided by Wagner's Law, public economy is affected by the nation's demand and willingness to pay for services where the income elasticity of demand for public services is elastic (Cameron, 1978). It is postulated that state governments will expand their expenditure if they have a greater level of income. Population growth is incorporated to capture the impact that demographics have on the state government's spending. In addition, the government is responsible for ensuring the provision of adequate public goods and services, and for sustaining the quality of life of local people who may be affected by the size of the subnational jurisdiction, which can be measured based on the size of the population (De Mello Jr, 2002). In this context, the greater the population, the larger the size of the subnational jurisdiction. It is assumed that states with higher population growth will bear higher costs of public service provision. This may cause state governments to allocate more spending to benefit all the people in terms of socioeconomic development. From another viewpoint, an increase in population would increase the tax base, giving more revenue to the state governments so that they can fulfil their expenditure responsibilities (Goudswaard \& Van de Kar, 1994). All the variables are transformed into logarithms except for the state-sourced revenue as a share of total public sector revenue and the state-sourced revenue as a share of the national average.

\section{2 | Regression framework}

By means of this analysis, we aim to determine whether the pattern of development expenditure across Malaysian states is affected by similar or different mechanisms of institutional factors during the short-term and the longterm. The key variables of interest in our study are federal transfers, total state revenue, state own-source revenue and inter-state differences in fiscal capacity. The convergence in development expenditure across states is analyzed based on annual growth for the short-term, and average 3-year and 5-year growth for the long-term. Our study consists of balanced panel data for 13 states from 2000 to 2015 . We employ the panel data approaches of pooled OLS, fixed effects and random effects.

First, we perform the Breusch-Pagan Lagrange Multiplier test for random effects. The chi-bar-square statistic reveals that the null hypothesis of consistency in the pooled OLS is rejected. Therefore, random effects estimation is preferred to pool OLS. Next, we evaluate the joint significance of state-specific fixed effects based on an Ftest. Again, the null hypothesis of the absence of specific effects is rejected. Hence, we proceed with fixed effects instead of pooled OLS estimation. In choosing an appropriate model, we use the Hausman test to decide between fixed effects and random effects. The test supports the rejection of the null hypothesis of using the random effects model in all conditional and unconditional convergence analyses except for the case of unconditional convergence during the short-term. Therefore, the fixed effects model is deemed reliable for explaining the fiscal behaviour of state governments in Malaysia. Furthermore, the fixed effects model has controlled timeinvariant variables, such as regional factors and 
individual state governments, which may have an impact on the estimation results. In addition, we cluster the state governments in obtaining robust standard errors, and control the time effect and correct for heteroscedasticity and autocorrelation using robust standard errors. The diagnostic test reveals that the model is free of the multicollinearity problem, as the variance inflation factor (VIF) for each variable is less than 10. Wooldridge (2013) reports that the value 10 is chosen as the cut-off value for VIFs. A multicollinearity problem exists if a VIF value is above 10 (p. 94). The Hausman test results and VIF scores are reported in the results tables in the following subheading.

\section{5 | FINDINGS AND DISCUSSION}

We first discuss the results for unconditional convergence, followed by those for conditional convergence. Table 2 shows the result for unconditional convergence in real government development expenditure across states in Malaysia. The Hausman test supports the rejection of the null hypothesis of using the random effects model in all unconditional convergence analyses except for the case of annual growth. In this regard, we report the results of random effects estimation for the shortterm (annual growth) but fixed effects estimation for both long-term (3-year average and 5-year average) growths. Based on Table 2, the significant negative coefficient of initial expenditure implies a decrease in the inter-state disparity in state government development expenditure over the period of 2000-2015. The coefficient of $\beta_{1}$ shows that the rate of convergence of government development expenditure across Malaysian states is higher in the longterm than in the short-term. The results imply that the convergence of states with lower initial development expenditure to those with higher initial development expenditure is more likely to occur within 3 and 5 years than 1 year. Statistically, a negative beta coefficient indicates that the lower the initial expenditure, the higher the growth of government expenditure towards the stable state. In other words, economies converge in terms of real government development expenditure at a speed of 0.06 percentage points per year and 0.3 and 0.23 percentage points on average over 3 and 5 years, respectively.

Next, the results for conditional convergence in real per capita development expenditure are provided in Tables 3-5 for annual, 3-year average and 5-year average periods, respectively. The Hausman tests reveal that the null hypothesis of using the random effects is rejected in all conditional convergence analyses. Therefore, the discussion of the conditional convergence is based on fixed effects estimation results, which have been reported in
T A B L E 2 Absolute or unconditional convergence: 2000 to 2015

\begin{tabular}{|c|c|c|}
\hline Dependent variable & Constant $\left(\beta_{0}\right)$ & $\begin{array}{l}\text { Initial } \\
\text { expenditure } \\
\left(\beta_{1}\right)\end{array}$ \\
\hline $\begin{array}{l}\text { Growth rate in } \\
\text { government } \\
\text { development } \\
\text { expenditure (annual) }\end{array}$ & $\begin{array}{l}0.3706(0.1725) \\
{[0.032]^{* *}}\end{array}$ & $\begin{array}{l}-0.0657 \\
(0.0240)[0.006] \\
\quad * * *\end{array}$ \\
\hline $\begin{array}{l}\text { Hausman test: Chi-sq. } \\
\text { statistics }\end{array}$ & 18.66 & \\
\hline $\begin{array}{l}\text { Growth rate in } \\
\text { government } \\
\text { development } \\
\text { expenditure (3-year } \\
\text { average growth) }\end{array}$ & $\begin{array}{l}1.5627 \\
(0.3734)[0.001] \\
* * *\end{array}$ & $\begin{array}{l}-0.3006 \\
(0.0656)[0.001] \\
\quad * * *\end{array}$ \\
\hline $\begin{array}{l}\text { Hausman test: Chi-sq. } \\
\text { statistics }\end{array}$ & $35.58^{* * *}$ & \\
\hline $\begin{array}{l}\text { Growth rate in } \\
\text { government } \\
\text { development } \\
\text { expenditure (5-year } \\
\text { average growth) }\end{array}$ & $\begin{array}{c}1.1563(0.2396) \\
{[0.482]^{* * *}}\end{array}$ & $\begin{array}{l}-0.2290 \\
(0.0471)[0.000] \\
\quad * * *\end{array}$ \\
\hline $\begin{array}{l}\text { Hausman test: Chi-sq. } \\
\text { statistics }\end{array}$ & $30.01^{* * *}$ & \\
\hline
\end{tabular}

Note: This table shows the results for unconditional convergence in real government development expenditure across states in Malaysia. Numbers in round and square brackets indicate robust standard errors and $p$-values, respectively. ${ }^{* * *},{ }^{* *}$ and $*$ denote statistical significance at the $1 \%, 5 \%$ and $10 \%$ levels, respectively.

Tables 3-5. For the whole analysis, the coefficient of $\beta_{1}$ in all models supports the idea that there is a convergence in development expenditure among Malaysian states during the period of 2000-2015. The speed of convergence is higher in the conditional models than it is in the unconditional model. However, the results show that the speed of convergence in the short-term is higher than it is in the long-term when we compare annual and average 3-year and 5-year growth analysis. This finding is contradicted by the earlier discussion of unconditional convergence results, which suggests that evidence of convergence is higher on average over 3 years than over 1. Additionally, there is evidence of convergence on average over 5 years, although the speed of convergence is lowest over this period. The speed of convergence lies between 0.44 and 0.53 points annually, as compared to between 0.44 and 0.48 points per year over 3 years. Meanwhile, the convergence rate is between 0.27 and 0.28 points in the case of a 5-year interval.

The conditional convergence in state government development expenditure in Malaysia shows a similar trend to what has taken place in other developing 
T A B L E 3 Conditional convergence in government development expenditure (annual growth)

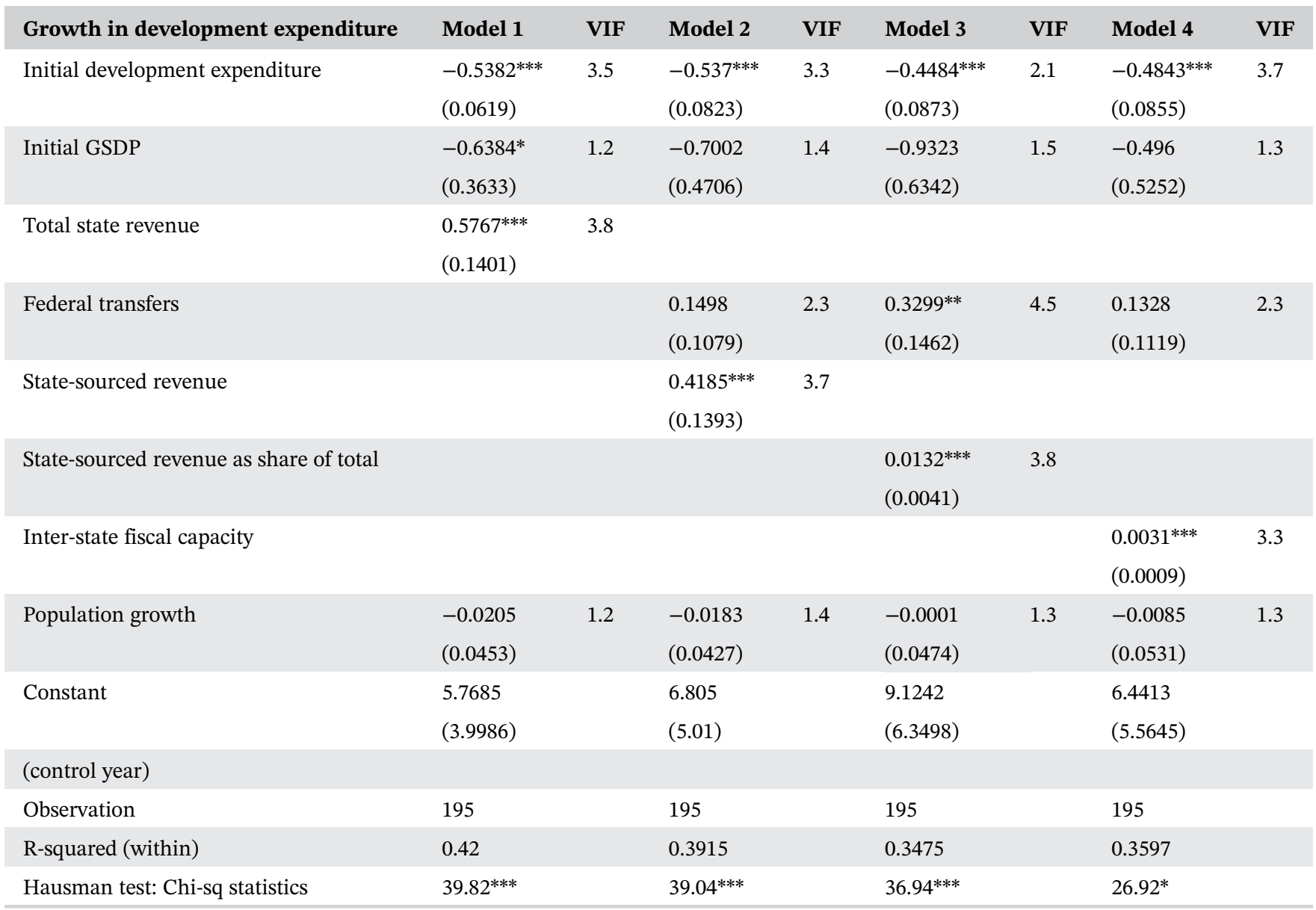

Note: This table shows the results for conditional convergence in real per capita development expenditure (annual growth). Numbers in brackets indicate robust standard errors. ${ }^{* * *},{ }^{* *}$ and * denote statistical significance at the $1 \%, 5 \%$ and $10 \%$ levels, respectively.

countries. Based on a 3-year average, a previous study by Kalirajan and Otsuka (2012) provides evidence of convergence in several categories of development expenditure in India at a rate of between 0.20 and 0.26 points. At longer than a 3-year interval, Kalirajan, Bhide, and Singh (2009) find that the convergence in development expenditure in India is slow, at a rate of 0.13 to 0.21 points. On the other hand, the latest research by Garg (2015) shows that annual growth in development expenditure in India converges at a rate of 0.33 to 0.46 points. These three studies support the consistent implication of our findings that the speed of convergence in development expenditure in a developing country such as Malaysia is faster within a short interval than it is over a longer interval. The findings of our study are also in line with Skidmore et al. (2004), who show empirical support for convergence in government consumption as well as capital and education spending in developing countries. Based on a 5-year interval, their convergence rate was slow, ranging from 0.02 to 0.1 points.
Based on the findings, we also show state government characteristics that are significant to the spatial equity in overall socio-economic development through the pattern of the expenditure. Beginning with model 1 , the results illustrate the importance of total state revenue to the growth rate of development expenditure as displayed in Tables 3-5. The positive beta coefficient implies that the increase in state revenue will increase the growth in government spending, with the impact highest over 1 year, followed by the average over the 3-year and 5-year periods. Based on model 2, it is suggested that state own-source revenue is an important source of the growth in government spending across all states. A one-point increase in the level of state own-source per capita revenue induces a higher growth in inter-state development expenditure of approximately 0.4 points over 1 year and on average over 3 years. However, the impact of state own-source revenue on the growth of expenditure is nearly half of those 0.4 points on average over a longer period of 5 years. Furthermore, the influence of the level of per capita transfers from 
the federal government on the pattern of state expenditure in Malaysia can be realized only over 3 years and no longer than that. These results imply that the level of state own-source per capita revenue has been a major factor in the growth in government expenditure, despite the level of per capita transfers from the federal government, which has a smaller influence on the change in government expenditure. In addition, the level of per capita transfers from the federal government is insufficient to promote short-term convergence in the growth of expenditure among states in Malaysia.

Similarly, in model 3, the results show that as state own-source revenue constitutes a higher share of the total revenue, higher growth is encouraged in government expenditure. Overall, a one-point increase in state ownsource revenue as a share of total revenue will escalate growth in government expenditure by over one point within 1 year and on average per year over 3 years but by less than one point on average per year over 5 years. Meanwhile, the level of per capita transfers from the federal government has a significant effect on the pattern of expenditure growth for Malaysian states, not just in the long-term but also in the short-term. A similar result is found as for model 2, with the level of per capita transfers having a greater effect on expenditure over 1 and 3 years, on average, than over 5. The results from model 2 and model 3 show evidence of state government reliance on federal transfers in generating their development spending.

Model 4 includes state own-source revenue as a share of the national average, to examine whether differences in inter-state fiscal capacity affect the spending decisions of Malaysian states. As expected, the higher the fiscal capacity of particular state governments relative to the average, the higher the growth in government spending in that state. A one-point increase causes growth in government expenditure to increase by $0.3,0.28$ and 0.13 points per year over 1,3 and 5 years, respectively. The impact of inter-state fiscal capacity on expenditure growth is smaller in the long-term than in the short-term. This result implies that relative fiscal capacity induces greater expenditure competition among Malaysian states over a short period than over a longer period.

T A B L E 4 Conditional convergence in government development expenditure (3-year average growth)

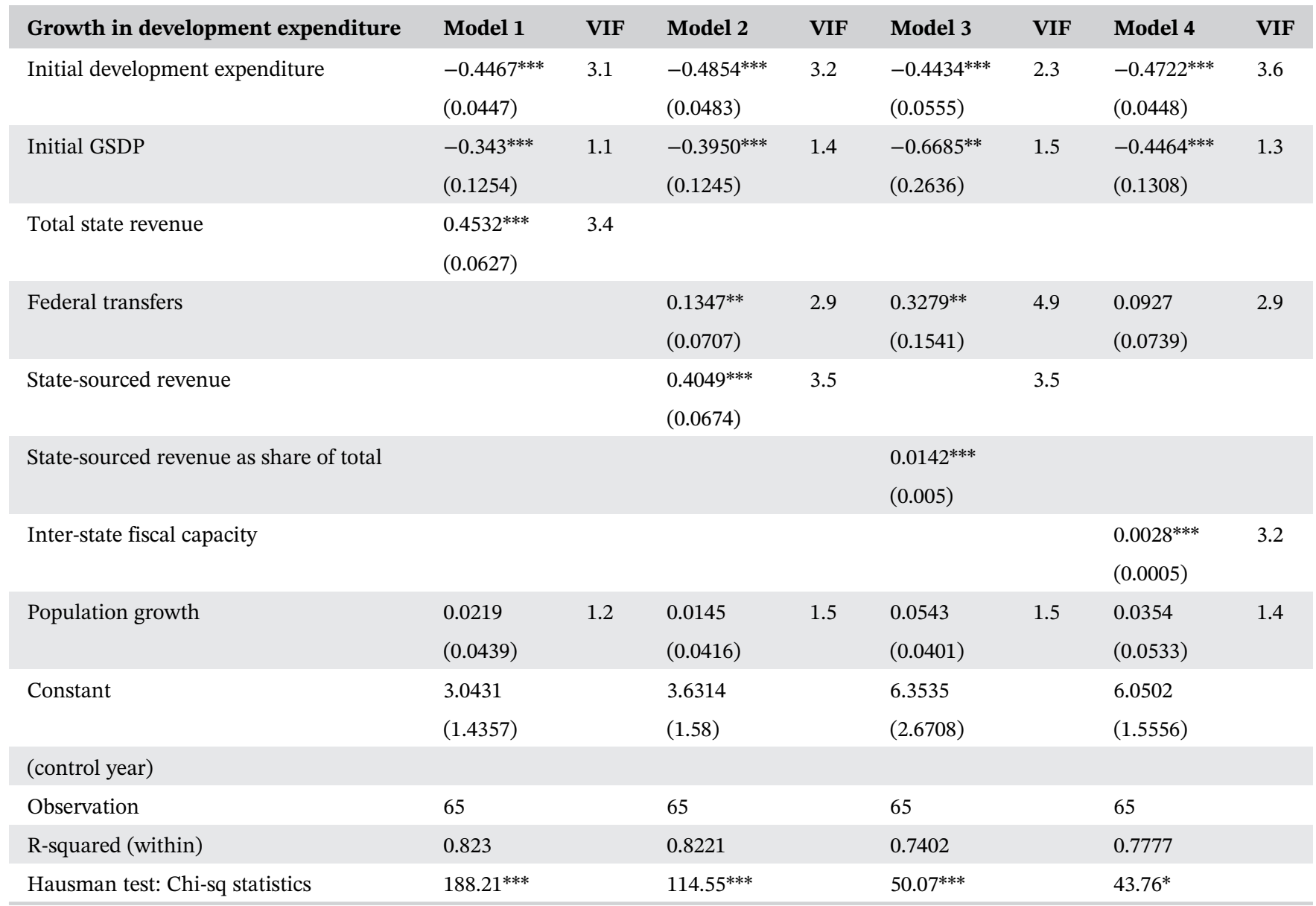

Note: This table shows the results for conditional convergence in real per capita development expenditure (3-year average growth). Numbers in brackets indicate robust standard errors. ${ }^{* * *},{ }^{* *}$ and ${ }^{*}$ denote statistical significance at the $1 \%, 5 \%$ and $10 \%$ levels, respectively. 
T A B L E 5 Conditional convergence in government development expenditure (5-year average growth)

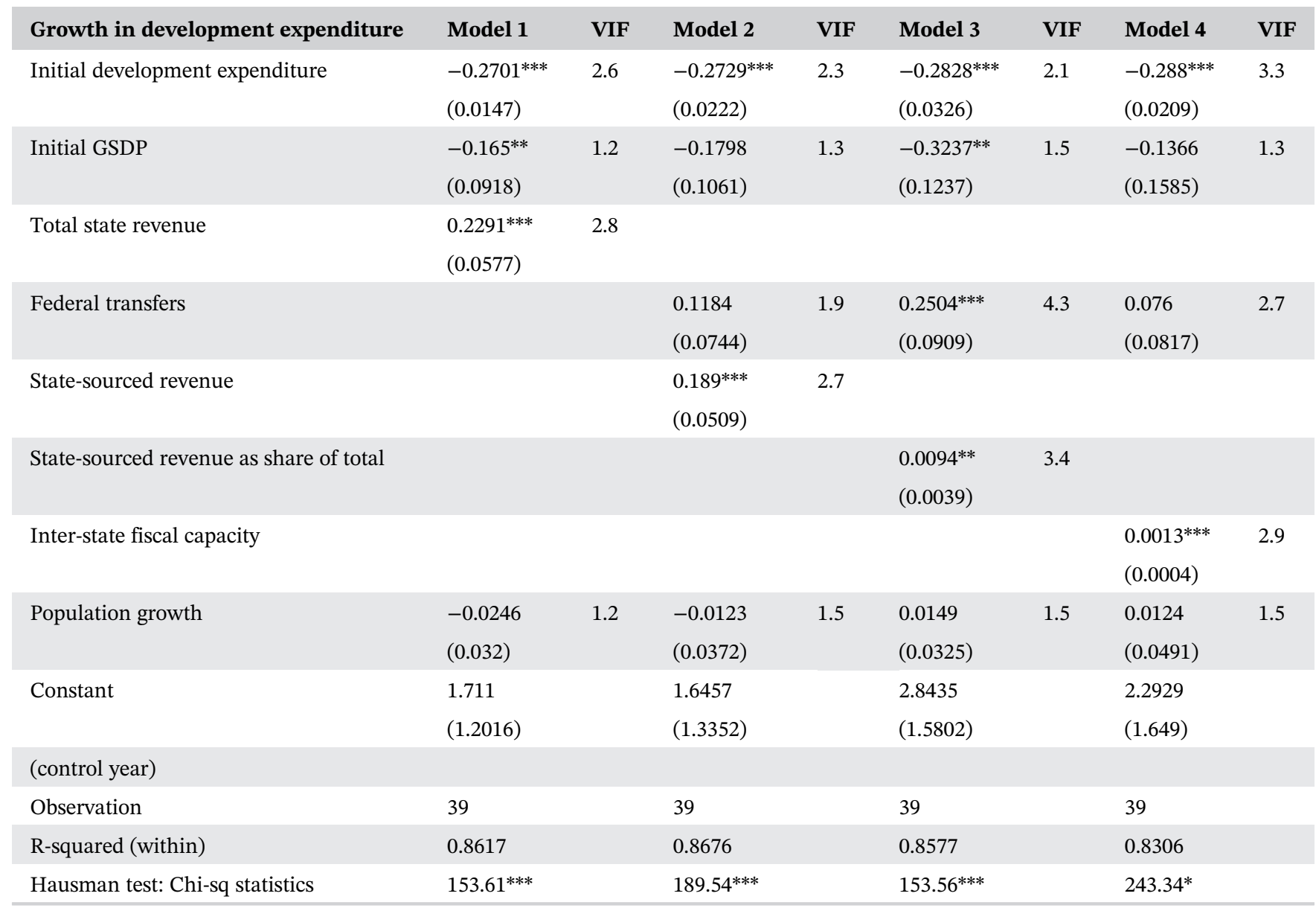

Note: This table shows the results for conditional convergence in real per capita development expenditure (annual growth). Numbers in brackets indicate robust standard errors. ${ }^{* * *},{ }^{* *}$ and ${ }^{*}$ denote statistical significance at the $1 \%, 5 \%$ and $10 \%$ levels, respectively.

Overall, the results indicate that all decentralization indicators that are measured based on per capita state revenue, state own-source per capita revenue, state own-source revenue as a share of total revenue, state own-source capacity as a share of the national average and per capita federal transfers are imperative in affecting spatial equitability in socio-economic development through the pattern of the development expenditure of the states in Malaysia. The significant positive influence of state revenue on government expenditure is consistent with the previous findings of Zhang, Zhang, Wu, Xia, and Lu (2016) and Kalirajan and Otsuka (2012). Other previous empirical works (Abdul Jalil \& Abdul Karim, 2008; Garg, 2015; Zhang et al., 2016) also support the relevance of federal transfers to the increase in state spending.

As for the other control variables, the estimates indicate that initial state per capita income measured by GDP (GSDP) has a significant negative effect on the growth of development expenditure across states in Malaysia.
Though Wagner's Law contradicts the negative effect of initial GSDP on the growth of development expenditure, the negative sign of the coefficient can be linked to the previous study of Abdul Jalil and Abdul Karim (2008), which found a negative relationship between a state's initial GDP and tax efficiency. Wagner assumes that growth of national income is vital for public spending, basically arguing that public sectors will grow as per capita income increases (Wagner, 1883). The study by Abdul Jalil and Abdul Karim (2008) shows that an increase in state per capita income reduces tax efficiency. This result implies that the negative effect of initial per capita income on growth in government spending happens because of tax inefficiency. In other interpretations, the negative coefficient of initial GSDP in relation to the growth in development expenditure also implies that an increase in GSDP will increase government development expenditure at a decreasing rate. Meanwhile, population growth is not significant in affecting the growth in development expenditure of states in Malaysia. 


\section{6 | CONCLUSION AND POLICY RECOMMENDATIONS}

Given the importance of government spending with respect to the variation observed in public services, we have examined the pattern of state government expenditure to determine whether there is a convergence in development expenditure and whether fiscal decentralization across states in Malaysia is functioning effectively. We have also analyzed the impact of the institutional factors of state government and federal government resources on changes in the fiscal behaviour of state governments. Generally, we find that state governments in Malaysia have fostered equitable spatial development through convergence in development expenditure. The rate of unconditional convergence is faster per year over durations of 3 and 5 years as compared to a 1-year period. However, the estimation results reveal that convergence has occurred more over 1 year than over 3 years when the impact of other factors, such as decentralization indicators, initial GSDP and state population growth, are considered. Evidence of convergence is also found over a longer period of 5 years, although the yearly convergence rate is slower in the shorter timeframes.

By and large, we find that total state revenue per capita, state own-source per capita revenue, state ownsource revenue as a share of total revenue and state ownsource capacity as a share of the national average have positive effects on the fiscal behaviour of state governments in Malaysia. Also, the level of per capita transfers from the federal government is vital to strengthening the expenditure capacity of the Malaysian states. These findings support the idea that the functioning of state

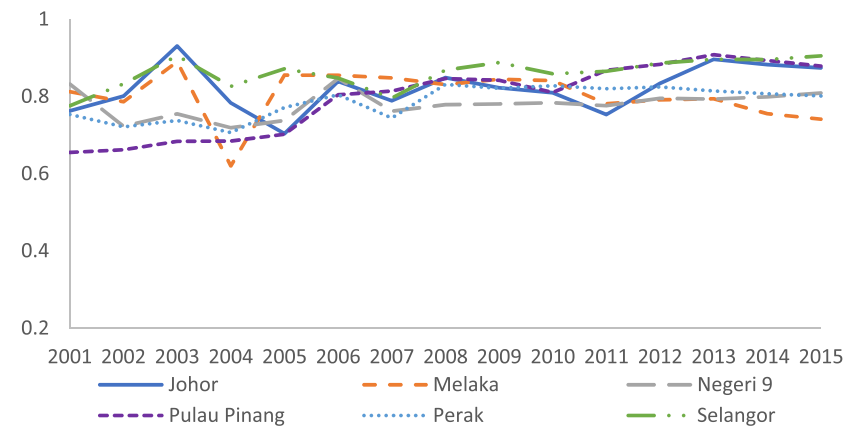

F I G U RE 2 Horizontal balance among developed states. Note: This figure shows state own-source revenue as a share of total state revenue of developed states: Johor, Melaka, Perak, Pulau Pinang, Negeri Sembilan and Selangor. All developed states earned ownsource revenue that was nearly $80 \%$ of their total state revenue. Source: Author's calculation [Colour figure can be viewed at wileyonlinelibrary.com] government matters for ensuring spatially equitable socio-economic development in the aspect of public finance. The effectiveness of the state governments at collecting revenue and managing the distribution of resources is vital to the process of development across states in Malaysia. Furthermore, these findings confirm that institutional factors play an important role in explaining the variation in growth or overall development across states in Malaysia resulting from the development expenditure of the states. Though the study does not explicitly explain the reasons for the persistent lag in the performance of less developed states, understanding the factors that affect the fiscal behaviour of the states might reduce this gap. In this context, maintaining less variation in state per capita revenue, state own-source per capita revenue, state own-source revenue as a share of total revenue and inter-state fiscal capacity might reduce the dispersion. Additionally, the government should take into account a further decentralization in the aspect of public finance because the state government has limited involvement in resource allocation and social and economic planning that has challenged the positive outcomes of decentralization. Furthermore, the federal government of Malaysia, through the transfer mechanism, should pay more attention to less developed states, as state own-source revenue in most of these states is insufficient for cultivating growth in their fiscal pattern of development expenditure, as shown in Figures 2 and 3. On the contrary, developed states have better fiscal capacity in terms of their own-source revenue, which is more adequate for their development expenditure compared to the less developed states.

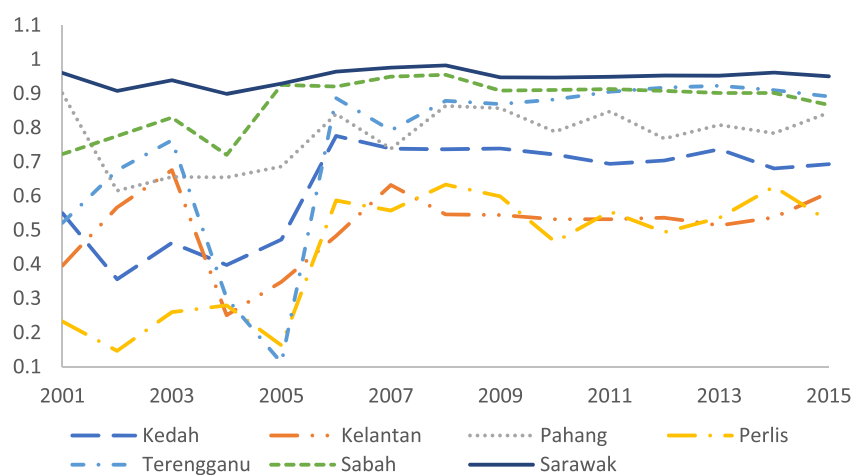

F I G U RE 3 Horizontal balance among less developed states. Note: This figure shows state own-source revenue as a share of total state revenue of less developed states: Kedah, Kelantan, Perlis, Pahang, Terengganu, Sabah and Sarawak. All less developed states except oil-revenue states (Terengganu, Sabah and Sarawak) earned own-source revenue that was lower than $80 \%$ of their total state revenue. Source: Author's calculation [Colour figure can be viewed at wileyonlinelibrary.com] 


\section{DATA AVAILABILITY STATEMENT}

Some of the data are confidential and needs a permission from government agency before it could shared publicly.

\section{ORCID}

Yusniliyana Yusof (i) https://orcid.org/0000-0002-42071566

\section{REFERENCES}

Abdul Jalil, A. Z., \& Abdul Karim, N. A. (2008). Understanding Malaysian state governments fiscal behavior: The role of intergovernmental transfers. Chulalongkorn Journal of Economics, 20(2), 113-141.

Afxentiou, P. C., \& Serletis, A. (1996). Government expenditures in the European Union: Do they converge or follow Wagner's Law? International Economic Journal, 10(3), 33-47.

Annala, C. N. (2003). Have state and local fiscal policies become more alike? Evidence of beta convergence among fiscal policy variables. Public Finance Review, 31(2), 144-165.

Anuar, A. R. (2000). Fiscal decentralization in Malaysia. Hitotsubashi Journal of Economics, 41(2), 85-95.

Apergis, N., Christou, C., \& Hassapis, C. (2013). Convergence in public expenditures across EU countries: Evidence from club convergence. Economics \& Finance Research, 1, 45-59.

Barro, R. J., \& Sala-i-Martin, X. (1990). Economic growth and convergence across the United States (No. w3419), Cambridge, MA: National Bureau of Economic Research.

Boadway, R. (2001). Inter-governmental fiscal relations: The facilitator of fiscal decentralisation. Constitutional Political Economy, 12, 93-121.

Cameron, D. R. (1978). The expansion of the public economy: A comparative analysis. The American Political Science Review, 72 (4), 1243-1261.

Deller, S., \& Skidmore, M. (2005). Convergence in local Government spending: Evidence from Wisconsin. Staff Paper Series (p. 483). University of Wisconsin-Madison.

De Mello, L. R., Jr. (2002). Public finance, government spending and economic growth: The case of local governments in Brazil. Applied Economics, 34(15), 1871-1883.

Economic Planning Unit (2015), The Eleventh Malaysian Plan Report, 2016-2020, Prime Minister's Department Malaysia, viewed September 12, 2016. Retrieved from http://www.epu. gov.my/en/rmk/eleventh-malaysia-plan-2016-2020

Economic Planning Unit (2013). Malaysian well-being report 2013, Economic Planning Unit Prime Minister Department of Malaysia.

Faguet, J., \& Shami, M. (2008). Fiscal policy and spatial inequality in Latin America and beyond. Policy research working paper series. Washington, DC: The World Bank.

Federal Constitution of Malaysia (2009). Laws of Malaysia. Reprint federal constitution incorporating all amendments up to P.U. (a) 164/2009. Malaysia.

Garg, S. (2015). Spatial convergence in public expenditure across Indian states: Implication of federal transfers'. Mumbai, India: Indira Gandhi Institute of Development Research.
Goudswaard, K., \& Van de Kar, H. (1994). The impact of demographic change on tax revenue. Atlantic Economic Journal, 22 (3), 52-60.

Gripaios, P. (2002). Regional spending: A comment on MacKay. Regional Studies, 36(6), 685-689.

Kaitila, V. (2005). Integration and conditional convergence in the enlarged EU area, ENEPRI Working Paper, No. 31. European Network of Economic Policy Research Institutes.

Kalirajan, K., \& Otsuka, K. (2012). Fiscal decentralisation and development outcomes in India: An exploratory analysis. World Development, 40(8), 1511-1521.

Kalirajan, K., Bhide, S., \& Singh, K. (2009). Development performance across Indian states and the role of the governments. ASARC Working Paper. Australia.

Kim, S. (2008). Spatial inequality and economic development: Theories, facts and policies, World Bank Working Paper, No. 16, Washington, DC.

Mackay, R. (2001). Regional taxing and spending: The search for balance. Regional Studies, 35(6), 563-575.

Pan, J., Wang, P., Qin, X., \& Zhang, S. (2013). Disparity and convergence: Chinese provincial government health expenditures. PLoS One, 8(8).

Skidmore, M., Toya, H., \& Merriman, D. (2004). Convergence in government spending: Theory and cross-country evidence. Kyklos, 57(4), 587-620.

Solow, R. M. (1956). A contribution to the theory of economic growth. The Quarterly Journal of Economics, 70(February), 65-94.

Sow, M. N., \& Razafimahefa, I. F. (2015). Fiscal decentralisation and the efficiency of public service delivery, IMF Working Paper.

Timakova, M. (2011). Conditional convergence and the Solow model: An empirical study. (Unpublished thesis). Erasmus University Rotterdam, Holland

Wagner, A. (1883). Three extracts on public finance, translated and reprinted. In R. A. Musgrave \& A. T. Peacock (Eds.), Classics in the theory of public finance. London, UK: Macmillan [1958].

Wilson, L. S. (1996). Federal-state fiscal arrangements in Malaysia, International and development studies working paper. Kingston, Canada: Queen's University, John Deutsch Institute for the Study of Economic Policy.

Wooldridge, J. M. (2013). Introductory econometrics: A modern approach (5th ed.). Mason, OH: South-Western, Cengage Learning.

Zhang, G., Zhang, L., Wu, S., Xia, X., \& Lu, L. (2016). The convergence of Chinese county government health expenditures: Capitation and contribution. BMC Health Services Research, 161, 408. https://bmchealthservres.biomedcentral.com/articles/10. 1186/s12913-016-1635-8

How to cite this article: Yusof Y, Kalirajan K, Mohamad A. Fiscal decentralization and convergence in government spending in Malaysia. Int J Fin Econ. 2020;1-13. https://doi.org/10.1002/ ijfe.2293 